\title{
THE PEPTOLYTIC POWER OF GASTRIC JUICE AND SALIVA WITH SPECIAL REFERENCE TO THE DIAGNOSIS OF CANCER *
}

\author{
J. L. JACQUE, M.D., AND R. T. WOODYATT, M.D. \\ CHICAGO
}

I.

In 1909 Neubauer and Fischer inaugurated the use of the dipeptid, glycyltryptophan, for the detection of peptid-splitting power in stomach contents, with special reference to the diagnosis of carcinoma. Their report called forth a shower of comments. It is not necessary to give a detailed account of the work, since this has been done repeatedly. But it may be recalled that it was based on an idea of Friedrich Müller that stomach contents from carcinoma patients could carry protein cleavage beyond the point at which normal peptic digestion ceases, and that this power was due to the presence in cancer tissue of an enzyme which could be secreted into the stomach.

Einerson showed that malignant growths actually contain an enzyme capable of splitting protein beyond the albumose phase, and in greater strength than that seen in benign growths, normal tissues, or in blood. $\mathrm{He}$ found similar properties in gastric contents from cancer patients. This work was confirmed and extended by $\mathrm{H}$. Fischer, and Neubauer and Fischer, who introduced the dipeptid glycyltryptophan as a reagent for the detection of peptid-splitting enzymes, and applied it in the study of a series of clinical cases which included twelve of carcinoma. The test consists in mixing glycyltryptophan with gastric juice, incubating the mixture and testing with bromin for the rose-violet color indicative of free tryptophan. They drew the following conclusions: 1 . In carcinomatous stomach contents a ferment occurs, which, unlike pepsin, splits glycyltryptophan. 2. The ferment is destroyed by 0.36 per cent. hydrochloric acid. 3. The presence of the ferment is usable in diagnosis ("ist diagnostisch verwendbar"). Since certain later writers have asserted that the test has no diagnostic value, we call attention to the conservative wording of the original.

In the examination of contents from pathological stomachs they recognized, a priori, certain sources of error: 1. Occurrence of tryptophan in the stomach contents themselves. 2. Presence of peptid splitting bac-

\footnotetext{
* From the Otho S. A. Sprague Memorial Institute Laboratory of Clinical Research, Rush Medical College.

* Mamuscript submitted for publication Sept. 2, 1912.
} 
teria. 3. Presence of trypsin (pancreatic juice). 4. Presence of blood (erepsin).

Concerning tryptophan in stomach contents as aspirated, much had already been written by Erdmann and Winternitz, Glaessner and Volhard. The conclusions of these writers, confirmed by Neubauer and Fischer, were to the effect that tryptophan seldom occurs in normal cases; that it frequently occurs in carcinoma and at times in certain non-malignant conditions associated with low acidity, and in motor insufficiency even with high acidity. Neubauer and Fischer regard such contents as unsuitable for application of their test. Concerning the influence of bacteria they conclude that simple filtration of the contents through paper is a sufficient safeguard. Refux of pancreatic juice interferes with the test, but since, save in cases of cessation of the outflow of bile, it seems hard to imagine reflux of intestinal contents into the stomach without bile, they advise testing for bile and discarding such specimens as contain it.

By the latter part of 1911 seven communications had appeared commenting on this work (Lyle and Kober, Ley, Kuttner and Pulvermacher, Weinstein, Ehrenberg, Oppenheimer and Pechstein). None of the writers attacked the principle of the test. All applied it to series of cases. All agreed that it was positive in most cases of cancer and negative in most normal cases. The reaction was observed, however, in non-malignant conditions associated with sub- or anacidity, and found negative in some cases of cancer. There was a manifest divergence of opinion as to the exact limits of its usefulness.

Lyle and Kober, Oppenheimer, and Pechstein reported in the main favorably; Weinstein objecting to the cost and stability of "ferment diagnosticum" (the commercial toluenized solution of glycyltryptophan marketed by Kalle \& Co., Biebrich a. R.), held that a direct bromin test for tryptophan in the stomach contents was simpler and more reliable than the glycyltryptophan procedure. In so doing he reverted, apparently unconsciously, to the older idea of Volhard and Glaessner. $\mathrm{He}$ disagreed with Neubauer and Fischer on minor points, but came to generally favorable conclusions, especially as regards the direct test for tryptophan after a protein meal. Kuttner and Pulvermacher also objected to the use of glycyitryptophan on the score of cost. They proposed using silk peptone instead and gauged its splitting by the observation of a precipitate of tyrosin under the microscope. They made eight parallel tests to establish the equivalence of the two procedures, and then, discarding the glycyltryptophan method, made a series of observations with silk peptone. From the results so obtained they came to highly unfavorable conclusions. They coincide with the views of those who regard reflux of pancreatic juice as a common occurrence, and consider 
the bile tests recommended by Neubauer and Fischer as inadequate for its exclusion. Ley and Ehrenberg had unfavorable experiences.

In a second communication published in 1911, the original writers review the literature up to that time. They point out that Kuttner and Pulvermacher employed a test differing from their own without adequately establishing the interchangeability of the two. Their analysis of the results obtained by all the above-mentioned writers indicates that out of all definitely proven cases of carcinoma studied, 84 per cent., and of the clinically diagnosed, 75 per cent., had shown positive reactions, while of the non-cancerous cases 14 per cent. were positive. They reiterate their cautions concerning blood and add that serum will also split glycyltryptophan, in illustration of which they cite a case of uremic gastritis in which a positive test was encountered. They disclaim ever having entertained the view that the test was in any sense specific. With the possible exception of the Bence-Tones albumose reaction in myeloma, clinical chemical tests are not generally to be so regarded. However, they maintain that when properly performed and considered in conjunction with other data, this procedure is, as originally claimed, an aid in diagnosis.

In the meantime other reports have appeared (Hall and Williamson, Warfield, Koehlker and Sanford and Rosenbloom). Hall and Williamson find positive reactions in most cases of cancer, but not in all. They also find some positive reactions in non-cancerous conditions and suspend their judgment. Warfield, working with saliva obtained from the mouth with no aseptic precautions, and relying on the use of toluene and sometimes centrifugation for exclusion of bacterial action, finds that saliva mixed with a solution of glycyltryptophan and incubated splits the latter, to give a positive tryptophan reaction with bromin. He suggests the possibility that bacteria may be responsible for this, but drops it with a negatively tending reference to Weinstein, and Neubauer and Fischer. Acids inhibit this action. 'The less acid in the stomach contents, according to Warfield, the greater the frequency of positive reactions, in benign as well as in malignant conditions. On the other hand, definitely cancerous contents with high combined acidities or with a relatively large amount of lactic acid are said to yield negative tests. He points out that although the presence of a peptid-splitting enzyme in cancer juice seems to have been demonstrated (and one may add in strengths greater than that of normal tissues including blood), the fact that carcinoma of the stomach is so often accompanied by absence of free hydrochloric acid, makes it "just the condition most favorable for a continuance of the salivary action"; then in concluding says: "In view of these facts the glycyltryptophan test is of no value in the diagnosis of cancer" (!) Koehlker, working from a theoretical standpoint with other di- and tripeptids whose spitting he detects with the polariscope, finds that all 
are hydrolyzed by saliva under experimental conditions similar to those used in Warfield's work. He is conservative in ascribing these effects to non-bacterial enzymes, but in view of the universal presence of ereptases in the tissues is inclined to the view that the peptid-splitting power of saliva is inherent.

In a second article Weinstein states that saliva is incapable of splitting Witte peptone. (As demonstrable by the bromin test for tryptophan.) Sanders and Rosenbloom disagree with this observation. From our own results it would appear that saliva as obtained from the mouth and protected with toluene frequently splits Witte peptone sufficiently to cause a marked increase in the formol-titrable nitrogen. Within twenty-four hours of incubation, however, we have not so far encountered positive tryptophan reactions. As regards the use of the glycyltryptophan test for cancer diagnosis, Sanders and Rosenbloom endorse the position taken by Warfield, that it is worthless.

II.

Having now presented the salient features of the literature, certain general observations may be made.

The principle that carcinoma tissue contains an enzyme capable of splitting polypeptids and in greater strength than is found in normal tissue, blood and non-malignant new growths, has not been disputed. All agree that in a large majority of the cases of gastric carcinoma, the stomach contents show the power to hydrolyze polypeptids. So far the possibility of devising a suitable procedure for detecting the cancer enzyme for diagnostic purposes would seem as great as it ever was. But the practical application of the glycyltryptophan procedure for this purpose has yielded inconstant results in the hands of different workers; some normal cases, many cases with low acidity and a few other nonmalignant conditions, have reacted positively; some cases of definite carcinoma have reacted negatively. Although some writers, expecting too much from an organic chemical reaction, have gone too far in depreciation of the test, it must be conceded that the greatest indefiniteness in results has been observed among the very group of cases in which the suspicion of carcinoma is justified by already existing methods, and among which differentiation is most to be desired. A non-malignant case with low acidity is likely to react positively; an early carcinoma developing on an ulcer base with high acidity is likely to be negative.

In deciding just how valuable the test is it makes a great deal of difference how we explain these variations, the variations which occur in spite of precautions such as Neubauer and Fischer recommend. If reflux of pancreatic juice into the stomach without the presence of readily detectable bile is a frequent phenomenon, as held by Kuttner and Pulvermacher in accordance with the view of Boldeyreff and others, then the 
test loses much of its value and no change in the details of its application will be likely to restore it. The pathologic-physiologic basis will have been undermined. If, as the work of Warfield and Koehlker appears to indicate, saliva possesses an enzyme which hydrolyzes polypeptids, the test in its present form falls to the level of a mere index of conditions in the stomach favorable for continuance of salivary digestion. Conceivably some means might be developed for eliminating these sources of error by controlling the reactions of the stomach contents or otherwise, but this is problematical. If, on the other hand, inconsistencies in the test are due to imperfections in the details of the method of applying principles which are correct, one might hope to eliminate the objectionable features.

Concerning the two most serious criticisms, that of Kuttner and Pulvermacher and that of Warfield, it is interesting to note that they are in part opposed to one another. One explains positive reactions in cases with low acidity by entrance of saliva through the cardia, the other by entrance of pancreatic juice through the pylorus. Both cannot be entirely right. If the reactions seen are due solely to saliva they are not due to pancreatic juice, and vice versa. The only ground for agreement would be the compromise that both processes are concerned.

Now there is no doubt that saliva as obtained from the mouth does in many cases contain something which has the power to cleave polypeptids. We have repeatedly confirmed this observation with glycyltryptophan and with Witte peptone.* It is equally certain that saliva passes normally into the stomach. Then given conditions in the stomach favorable for a continuance of this action and it follows that peptid splitting must occur there for this reason alone. In view of this consideration it is clear that the mere demonstration of polypeptid splitting power in gastric juice carries with it no proof of any second enzyme entering from the pylorus. Unless there are other proofs that pancreatic juice may gain access to the stomach than the mere detection of peptid splitting, or until such splitting is observed under conditions which preclude the effect associated with saliva, one is not warranted in the assumption that any reflux of pancreatic juice actually occurs. For the combined effects of pepsin and saliva are equal to the effect of trypsin. Boldyreff, Kuttner and Pulvermacher and others, have never excluded this source of error and the burden of proof lies with them.

Let us now consider more in detail the question of saliva. If pure sterile saliva contains an enzyme which can split peptids, the test has a limited value. If the observed splitting is due to bacteria, it is less serious obstacle. We have tested the action of saliva before and after passage through a Berkefeld candle and have never seen any peptid splitting power in the filtered sccretion, although it was frequently observed in the unfiltered samples, and again in the filtered, after these

"In some samples of saliva, however, we have failed to demonstrate any peptolytic power. 
had been inoculated with a mere loopful of the former. The process of filtration did not impair the amylolytic power of the saliva and we feel safe in the assertion that non-filterable bodies in the saliva are responsible for its apparent peptid splitting action. These non-filterable bodies are here regarded as bacteria, although some have suggested the possibility of a selective filtration of enzymes. Theoretically it would make no essential difference as to the effects which are seen in the stomach contents whether the action were bacterial or due to a secreted enzyme. The same chemical conditions might favor either, and on the other hand, high acidities, whether due to $\mathrm{HCl}$ or to an unusual quantity of lactic acid, would check bacteria as well as the enzyme. Warfield's results might be interpreted in this way as well as in another. All are familiar with the inhibition of the growth of certain bacteria in milk or in the bowel by the predominance of lactic acid bacilli and their product. Practically it is certain that whatever gives saliva its peptolytic power this can be effectually eliminated by mechanical means. Toluene is not free from objections.

Since heretofore no greater precautions have been taken in the study of peptolysis in stomach contents than in saliva, it is obvious that unless the conditions in the stomach are such as to check bacterial action already begun the same remarks apply here as have just been made for saliva concerning the chances of confusing bacterial action with that of native enzymes. Especially when there are infected teeth, gums or tonsils, and catarrhal processes in the nasopharynx or ragged ulceration in the gastric mucosa itself, will the chances for bacterial action be great. The experiments made by Neubauer and Fischer to determine how much attention should be paid to bacteria did not exclude the possibility that a heterogeneous mass of organisms in such culture media as may occur in subacid stomach contents, may actively split peptone. Nor is the simple filtration through paper, which they recommend, a reliable safeguard against, this source of error. Papers vary; some are fairly effective, others not.

Up to this point, then, we find no basic objection to their test, but see in the inadequate provisions for excluding bacteria one explanation for disagreement among different observers. There are also other points to be considered. When gastric juice is mixed with a solution of glycyltryptophan and the cleavage of the latter is detected by application of a bromin test, we end with a delicate and easily-masked color reaction, a purely qualitative test permitting scarcely a guess as to the extent of the splitting. Even then we are dealing solely with the cleavage of a single dipeptid. A given stomach content might cleave other peptids in greater quantity in one case, less in another. The substitution of Witte peptone or silk peptone for glycyltryptophan introduces a theoretical difference even though in the end we gauge the cleavage by testing qualitatively for a single end-product. If we use Witte peptone and rely on the bromin test as an index of its splitting, we fail to observe any 
cleavages except those which in the end liberate free tryptophan; hence considerable hydrolysis of this substance can occur before a positive bromin test is obtainable. The same applies to the use of silk peptone and observance of the tyrosin precipitate. On the other hand, a positive test implies a whole succession of hydrolyses which have carried the peptone down to its simplest components. For this very reason peptone may be a more suitable substance to use for clinical purposes. Theoretically glycyltryptophan should be a more delicate reagent than peptone under these conditions, because it cannot split at all without giving the substance (tryptophan) used as the index. Possibly it is too delicate for clinical purposes.

The greatest consistency in results might be expected from a quantitative method which would tell us the total peptid splitting power of a given gastric juice, acting under definite conditions for a definite time on a uniform mixture of polypeptids. Such a test should give us a set of figures from which to draw conclusions as to the amount of splitting which is to be regarded as normal, what the limits for the normal are, how much splitting power a positive qualitative tryptophan test corresponds to, how much splitting can occur in the non-malignant diseases, how much in cancer, etc. Such relative figures based on a series of observations naturally would not be regarded as absolute, but they should enable us to classify stomach contents on the basis of polypeptid splitting power in the same way that we now compare them on the basis of acidity.

For this purpose we have used a 2 per cent. aqueous solution of Witte peptone which is mixed with gastric juice and subjected to formol titration in accordance with the method of Ronchése-Malfatti-Sörenson. After titration of a 10 -c.c. sample of the mixture the remainder is placed in the incubator and after twenty-four hours retitrated. The excess of peptone by combining any free acid which may be present makes further neutralization unnecessary.

In applying this method in a series of cases, we have aimed especially to ascertain (1) whether normal gastric juice and saliva split peptone at all, and, if so, to what extent; (2) how much of the peptid-splitting power which has been observed in saliva, and in gastric juice of nonmalignant diseases, is due to bacteria; and whether, if the action of bacteria is certainly excluded, there still remains in such gastric juices any splitting power which would have to be ascribed to reflux of panceratic juice unaccompanied by bile; (3) how much of the peptid splitting seen in cancer cases is due to bacteria and how much is due to other causes (e. g., cancer enzyme) ; (4) the value in diagnosis of the quantitative method as compared to that of simply testing for tryptophan in the Witte peptone, gastric juice mixtures after incubation, and in general the 
diagnostic value of any method for detecting polypeptid or peptid splitting power in gastric juice. ${ }^{1}$

III.

The results obtained may be summarized as follows:

Saliva as obtained from the mouth, filtered simply through paper and incubated under toluene, often but not always has the power to split Witte peptone and glycyltryptophan. But if the saliva is filtered through a Berkefeld candle and kept aseptic, all detectable peptolysis disappears. 'The same is true for its power to split glycyltryptophan. If the aseptic peptone-saliva mixture be inoculated with a drop of unfiltered saliva, peptolysis again occurs (Table 1 ).

The peptolytic power of gastric juice (and blood) has been estimated in terms representing the increase in the number of c.c. of $\mathrm{N} 10 \mathrm{KOH}$ required in the formol titration of 100 c.c. gastric juice (or serum) with 200 c.c. 2 per cent. Witte peptone solution after twenty-four hours incubation at body temperature. This figure, here designated as the peptolytic index, is used for comparisons.

The peptolytic index for pure, fresh blood-serum from healthy individuals was found to average 8 , part of the rise being due to autolysis of the serum itself.

For normal gastric juice as studied in forty cases, the minimum was 0 , maximum 18 , average 10.5 , or about that found for serum. In none of the forty cases was there a positive color test for tryptophan before or after incubation with peptone solution (Table 2 ).

In ten cases of hyperacidity the minimum index was 0 , maximum 6 , average .6 (lower than the normal). (Table 3.)

In twenty-two cases of subacidity and anacidity in which the free HCl ran from 10 to 0 , total acidity 20 to 5 , the maximum peptolytic index was 33 ; minimum .0, average 9 (Tables 4 and 5 ).

The indices, then, were lowest in hyperacidity, a little higher in the normal, a little higher yet in some of the stomach contents from cases of an- and subacidity. For this entire group of seventy-six normal and non-malignant cases the inverse relationship between acidity and pepto-

1. We had intended also to compare the results obtained by the Neubauer and Fischer method with those obtained by simple substitution of Witte peptone for glycyltryptophan, and those of the quantitative method herein described. But at the time this work was begun (some two years ago), we had trouble in obtaining "ferment diagnosticum." We regret, therefore, ou: inability to state whether in a long series of cases substitution of Witte peptone for the dipeptid is more or less advantageous, except by comparing our results with the published results of others. Such comparison suggests that Witte peptone is less likely to yield a positive result in non-malignant conditions and equally reliable in cancer cases. Perhaps glycyltryptophan, for reasons already mentioned, is too sensitive. The peptone is also cheaper. 
lysis as observed for glycyltryptophan by Warfield, seems to hold good. 'Tryptophan reactions were, however, uniformly negative.

One case of non-malignant stenosis gave a positive tryptophan reaction with bromin. In this instance stomach contents were examined on three different days. The indices ran .0, 7 and 9 , average 5.3, or well within the normal limits. This shows the possibility of encountering now and then a positive color reaction with what may be regarded as a "normal" peptolytic power. It explains possibly some of the discrepancies in results obtained by qualitative methods. Since theoretically "ferment diagnosticum" should show free tryptophan to the bromin test with a slighter peptid splitting power than with peptone, for reasons already given ( $p .566$ ) it may well be that this dipeptid is even more likely than peptone to give a positive result with a normal case.

Four of the samples in the subacidity series which showed the highest peptolysis were filtered through a Berkefeld filter and mixed with peptone solution under aseptic conditions. In cases so treated the index always became 0 . (Table 5, Cases $113,114,115,11 \%$.) This observation, together with the point previously mentioned, that in non-malignant cases peptolysis and acidity are in an inverse relationship, indicates that in these benign cases, peptolysis is due to bacteria whose action is inhibited by acid.

'I'wenty-three cases of cancer have been studied from which thirtythree samples of gastric juice were obtained (Tables 6 and 7 ). In all cases the diagnosis was made at operation or at autopsy. Six of the malignant series were cases of carcinoma developing on an ulcer base, with free $\mathrm{HCl}$ between 15 and 20, total acidity 60 to 70 (Table 6, last six cases). In this group, in spite of acidities above those of the non-malignant cases, the indices ran, maximum 72 , minimum 48 , average 69 ; i. e., the minimum index is once and a half that of the maximum found in forty normal and thirty-six non-malignant subacidity cases. The tryptophan reaction after incubation with Witte peptone was positive in all. These findings do not confirm the views of Warfield that peptolysis is due to a salivary enzyme which fails to act when the acidity is high. Twelve of the fourteen cancer cases with free $\mathrm{HCl} 0$, and total acidity between 5 and 10 (Table 7 ), gave indices as follows: maximum 165, minimum 63 , average 98.5 ; i. e., the least index was twice as great as the maximum non-malignant figure encountered, while the maximum was five times as great. The average was nearly ten times that of the normal average (10.5).

The qualitative tryptophan test was positive in thirteen of the fourteen, and failed in one case (Case 75) in spite of the low acidity and the excessive peptolysis shown by titration. Two of the fourteen cancer cases 
(Table \%, Cases 60 and 86) gave indices not so greatly exceeding the highest non-malignant figures.

In four cases doubt had existed as to the diagnosis. In each of these the free $\mathrm{HCl}$ and total acidity were 5 and 15 , respectively (by coincidence). The peptolytic indices by the antiseptic method averaged 148; minimum 120 , maximum 165 . The tests in this series were also made by the aseptic method (filtration through a Berkefeld candle and subsequent use of sterile pipettes and flasks without toluene). The indices then averaged 97.5, maximum 105, minimum 8\%. Peptolysis was reduced by the filtering, but only moderately so and remained on the average nearly ten times as high as the normal average, even when for the latter we take the figures of the toluene method. Exploratory operation was made and revealed carcinoma in each case (Cases 99, 112, 120, 122; Table 7).

TABLE 1.-Tests with SALIVA

Saliva, 1 part; sterile peptone solution, 2 parts. Of the mixture 10 c.c. subjected at once to formol titration; a second 10 c.c. incubated for twenty-four hours with addition of acid or alkali as indicated under remarks. $A$ indicates that toluene was used for antisepsis; $B$, that the saliva was filtered through a Berkefeld filter and handled aseptically. The table shows comparative effects of toluene and filtration; also the high peptolysis when neither is used.

\begin{tabular}{|c|c|c|c|c|c|}
\hline \multirow[b]{2}{*}{$\begin{array}{l}\text { No. of } \\
\text { Exper. }\end{array}$} & \multicolumn{3}{|c|}{ - Formol Titration } & \multirow[b]{2}{*}{$\begin{array}{l}\text { Br. } \\
\text { Test }\end{array}$} & \multirow[b]{2}{*}{ Remarks } \\
\hline & $\begin{array}{c}\text { Before } \\
\text { Ineuba- } \\
\text { tion }\end{array}$ & $\begin{array}{c}\text { After } \\
\text { Incuba- } \\
\text { tion }\end{array}$ & Rise & & \\
\hline I & 1.5 & 2.0 & 0.5 & 0 & A. No addition of acid or alk. \\
\hline II & 1.1 & 2.1 & 1.0 & 0 & A. Made alkaline to litmus. \\
\hline III & 1.0 & 1.3 & 0.3 & 0 & A. Made alk. to phenolphthalein. \\
\hline IVa & 0.9 & 1.1 & 0.2 & 0 & A. Added N/10 to make $.18 \%$. \\
\hline $\mathrm{IVb}$ & 0.9 & 1.1 & 0.2 & 0 & A. Added $\mathrm{N} / 10$ to make $.36 \%$. \\
\hline IV $\mathrm{c}$ & 0.9 & 1.0 & 0.1 & 0 & A. Added N/10 HCl to make $18 \%$. \\
\hline $\mathrm{Va}$ & 1.1 & 1.3 & 0.2 & 0 & A. No addition. \\
\hline $\mathrm{Vb}$ & 1.1 & 7.2 & 6.1 & 0 & Same with toluene omitted. \\
\hline $\mathrm{Ve}$ & 1.1 & 1.1 & 0.0 & 0 & B. No addition. \\
\hline$V_{I}$ & 1.4 & 1.4 & 0.0 & 0 & B. No addition. \\
\hline VIb & 1.4 & 2.5 & 1.1 & 0 & Same reinfection with fresh saliva. \\
\hline VII & 4.5 & 4.5 & 0.0 & 0 & B. No addition. \\
\hline
\end{tabular}

In one case the contents were obtained at autopsy. By the usual method of examination with filtration through paper and incubation under toluene, the index was 186 ; with no toluene added it was 219 ; after filtration through porcelain without using toluene, 129, showing the inhibiting effect of toluene to be less than that of filtration. The figures obtained in the last five cases cited also show that neither filtration nor toluene, nor a combination of the two will eliminate the peptolytic power from certain cancerous stomach contents, from which it is apparent that, unlike what was found for benign and normal conditions, we have to do in cancer cases with two peptolytic fractions, viz., microorganisms and something filterable. The filterable peptolyzing agent might be regarded as an extracellular enzyme from bacteria or a ferment from cancer. Saliva and normal gastric juice and that from subacidity cases, however, 


\section{TABLE 2.-Tests with Gastric Juice-Normal Cases}

Table made from the data obtained in forty cases. No symptoms in any. Free $\mathrm{HCl}, 30-40$. Total acidity, 50-60 in all. Bile, blood and lactic acid tests negative in all. Table includes the extremes and averages of 40 cases.

\begin{tabular}{|c|c|c|c|c|c|c|c|}
\hline \multirow{2}{*}{ ase } & \multicolumn{3}{|c|}{ - Formol Titration -- } & $\stackrel{\substack{0 \\
0}}{=}$ & \multicolumn{2}{|c|}{ Acidity } & \multirow{2}{*}{ Remarks } \\
\hline & $\begin{array}{l}\text { Incuba- I } \\
\text { tion }\end{array}$ & $\begin{array}{l}\text { Incuba- } \\
\text { tion }\end{array}$ & Rise & $\dot{\vec{\varphi}}$ & $\mathrm{HCl}$ & Total & \\
\hline 65 & .6 & 1.2 & .6 & 0 & 30 & 58 & $\begin{array}{l}\text { Case which showed greatest } \\
\text { peptolysis. }\end{array}$ \\
\hline & .5 & $\begin{array}{l}.5 \\
.8\end{array}$ & $\begin{array}{l}0 \\
0\end{array}$ & $\begin{array}{l}0 \\
0\end{array}$ & $\begin{array}{l}39 \\
40\end{array}$ & $\left.\begin{array}{l}56 \\
58\end{array}\right\}$ & $\begin{array}{l}\text { Two characteristic cases with } \\
\text { no demonstrable peptolysis. }\end{array}$ \\
\hline & .6 & .95 & .35 & 0 & 35 & 55 & Averages from 40 cases. \\
\hline
\end{tabular}

Peptolytic index: Max. 18; Min. 0; Av. 10.5.

Table 3.-Tests with Gastric Jurce--Hyperacidity Cases

Ten cases, with $\mathrm{HCl} 50-80$; total acidity 70-110. Bile, blood and lactic acid always absent and no sign of dilatation or obstruction. Symptoms such as occur commonly in "hyperchlorhydria" with nothing to suggest, directly, ulcer or other organic stomach disease; (or, no symptoms, the hyperacidity having been discovered by routine).

\begin{tabular}{|c|c|c|c|c|c|c|c|}
\hline \multirow{2}{*}{$\begin{array}{l}\text { Case } \\
\text { No. }\end{array}$} & \multicolumn{3}{|c|}{ - Fornol Titration - } & $\underset{0}{i_{2}}$ & \multicolumn{2}{|c|}{ Acidity } & \multirow{2}{*}{ Remarks } \\
\hline & $\begin{array}{c}\text { Incuba- } \\
\text { tion }\end{array}$ & $\begin{array}{l}\text { Incuba- } \\
\text { tion }\end{array}$ & Rise & $\dot{\vec{n}}$ & $\mathrm{HCl}$ & Total & \\
\hline 3 & .3 & .3 & 0 & 0 & 60 & 70 & \\
\hline 14 & .2 & .2 & 0 & 0 & 60 & 75 & Epileptic. \\
\hline 21 & .2 & .2 & 0 & 0 & 65 & 90 & \\
\hline 32 & .2 & .2 & 0 & 0 & 70 & 98 & \\
\hline 44 & 1.2 & 1.2 & 0 & 0 & 50 & 70 & \\
\hline 46 & 1.2 & 1.4 & .2 & 0 & 81 & 109 & Morning aspiration. \\
\hline 48 & 1.0 & 1.0 & 0 & 0 & 56 & 76 & \\
\hline 50 & 1.6 & 1.6 & 0 & 0 & 69 & 85 & \\
\hline 41 & 1.5 & 1.5 & 0 & 0 & 63 & 111 & \\
\hline 52 & .6 & .6 & 0 & 0 & 72 & 86 & \\
\hline
\end{tabular}

Peptolytic index: Max. 6.0; Min. 0; Av. .6.

TABLE 4.-Tests witu Gastric Juice-Subacidity Cases, a

Ten cases with free $\mathrm{HCl}$ 10-15; total acidity 25-30. Bile, blood and lactic acid tests uniformly negaiive.

\begin{tabular}{|c|c|c|c|c|c|c|c|}
\hline \multirow{3}{*}{$\begin{array}{l}\text { Case } \\
\text { No. }\end{array}$} & \multicolumn{3}{|c|}{ - Formol Titration - } & & \multirow{2}{*}{\multicolumn{2}{|c|}{ Acidity }} & \multirow{3}{*}{ Remarks } \\
\hline & Before & \multirow{2}{*}{$\begin{array}{l}\text { After } \\
\text { Incuba- } \\
\text { tion }\end{array}$} & \multirow[b]{2}{*}{ Rise } & \multirow{2}{*}{$\dot{\vec{n}}$} & & & \\
\hline & $\begin{array}{c}\text { Incuba- } \\
\text { tion }\end{array}$ & & & & $\mathrm{HCl}$ & Total & \\
\hline 23 & .8 & .8 & 0 & 0 & 12 & 25 & Symptoms in these cases were \\
\hline 24 & 1.5 & 1.5 & 0 & 0 & 8 & 15 & mild, e. g., anorexia, weight \\
\hline 25 & 1.0 & 1.2 & .2 & 0 & 10 & 20 & or distress p. c. with head- \\
\hline 51 & 1.0 & 1.3 & .3 & 0 & 10 & 26 & ache and neurasthenic symp- \\
\hline 53 & .4 & .7 & .3 & 0 & 10 & 30 & toms. Physical findings \\
\hline 64 & .9 & 1.3 & .4 & 0 & 5 & 12 & were negative; no ptoses, \\
\hline 88 & 1.3 & 1.3 & 0 & 0 & 10 & 26 & no dilatations, no motor \\
\hline 100 & .7 & 1.0 & .3 & 0 & 12 & 15 & incufficiencies. In three cases \\
\hline 104 & .7 & 1.0 & .3 & 0 & 10 & 25 & diarrhea was present. \\
\hline 54 & .9 & 1.5 & .6 & 0 & 6 & 24 & \\
\hline
\end{tabular}

Peptolytic index: Max. 18; Min. 0; Av. 7.2. 
completely lose their peptolytic power with suitable filtration, from which it would appear that filtration is adequate for eliminating bacterial action. Others have shown that cancer tissues, aseptically prepared, do contain a peptolytic enzyme. Therefore it seems more plausible to ascribe the filterable agent to the cancer. Our own work, however, does not finally establish this point. Possibly a cancerous mucosa lodges bacteria which do not thrive under other conditions.

\section{Table 5.-Tests with Gastric Juice-Subacidity Cases B}

Sixteen cases. Free $\mathrm{HCl}, 0$; total acidity 8 to 30 . In four of these cases $(113,114$, 115,117 ) filtration was carried out through a Berkefeld filter with subsequent aseptic handling, and also by the usual paper filtration with subsequent antiseptic (toluene) treatment.

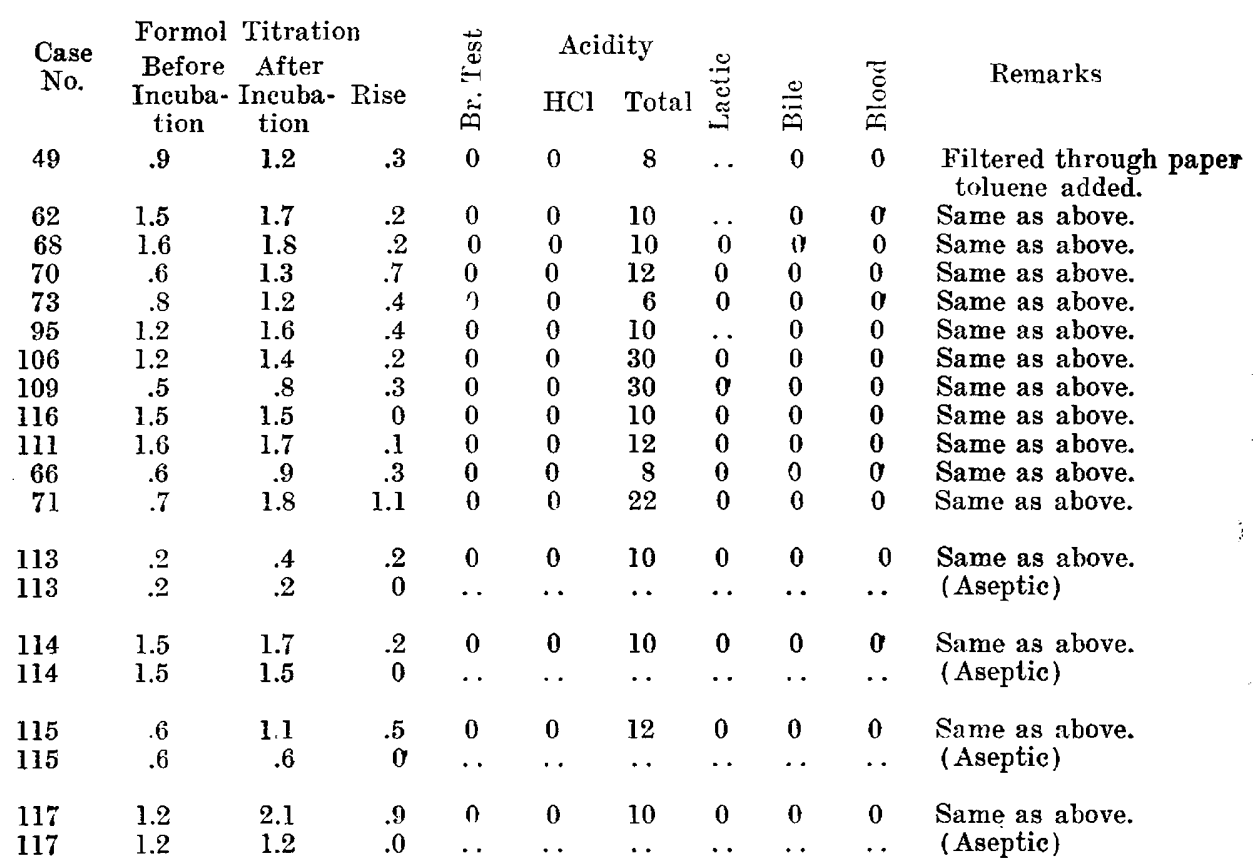

Peptolytic index: Max. 33; Min. 0; Av. 10.5; 16 cases (usual method).

Peptolytic index: Max. 0; Min. $0 ;$ Av. $0 ; 4$ cases (aseptic method).

Three cases of carcinoma showed indices of 0,6 and 12 , no higher than the benign series, and hence negative (Table 6; Cases 33, 87, 92). In one of these cases there was the high lactic acid content which Warfield found associated with negative glycyltryptophan reactions; in the others the acidities were low. In all, 88 per cent. of the cancer cases were positive by the quantitative method, 83 per cent. by the qualitative. Of seventy-six non-malignant cases, only one gave a positive tryptophan test. 
In the series of cases here reported, the maximum index found in any of seventy-six benign cases by the toluene method was thirty-three, and this was seen in but one case. The minimum index in the cancer cases, barring three, was forty-five. For practical purposes we may say then that when reliance is placed on paper filtration and toluene

Indices of $0-20$ are negative.

Indices of 20-40 are suspicious.

Indices of 40 and over are positive.

TABLE 6.-Malignant Cases

Nine cases of earcinoma with free $\mathrm{HCl}, 0$ to 20 ; total acidity, 5 to 70 . Diagnosis confirmed in all but two obvious cases either at operation or at autopsy.

\begin{tabular}{|c|c|c|c|c|c|c|c|c|c|c|c|}
\hline \multirow{2}{*}{\multicolumn{2}{|c|}{$\begin{array}{l}\text { Case } \\
\text { No. }\end{array}$}} & \multicolumn{3}{|c|}{ Formol Titration } & $\vec{a}$ & \multicolumn{3}{|c|}{ Acidity } & & & \multirow{2}{*}{ Remarks } \\
\hline & & First & Second & Rise & $\dot{\bar{m}}$ & $\mathrm{HCl}$ & Total & $\stackrel{D}{=}$ & $\frac{\check{g}}{m}$ & 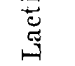 & \\
\hline $\begin{array}{l}33 \\
87 \\
92\end{array}$ & & $\begin{array}{l}1.2 \\
1.2 \\
1.5\end{array}$ & $\begin{array}{l}1.4 \\
1.2 \\
1.9\end{array}$ & $\begin{array}{l}.2 \\
.0 \\
.4\end{array}$ & $\begin{array}{l}0 \\
0 \\
0\end{array}$ & $\begin{array}{l}0 \\
0 \\
0\end{array}$ & $\begin{array}{r}6 \\
36 \\
5\end{array}$ & $\begin{array}{l}0 \\
\mathbf{0} \\
0\end{array}$ & $\begin{array}{l}0 \\
0 \\
0\end{array}$ & $\underset{0}{++}$ & $\begin{array}{l}\text { Negative Cases: All were oper- } \\
\text { ated on. Cases } 33 \text { and } 92 \text { show- } \\
\text { ed cancer at lesser curvature; } \\
\text { Case } 87 \text { cancer at pylorus. Note } \\
\text { low acidity in two cases. }\end{array}$ \\
\hline 118 & ${ }^{*}$ A.M. & $\begin{array}{l}1.7 \\
2.0\end{array}$ & $\begin{array}{l}4.0 \\
4.4\end{array}$ & $\begin{array}{l}2.3 \\
2.4\end{array}$ & + & $\begin{array}{r}10 \\
8\end{array}$ & $\begin{array}{l}30 \\
21\end{array}$ & $\begin{array}{l}0 \\
0\end{array}$ & $\begin{array}{l}0 \\
0\end{array}$ & $\begin{array}{l}0 \\
0\end{array}$ & \\
\hline 37 & A.M. & 2.1 & 4.6 & 2.5 & + & 15 & 70 & 0 & 0 & 0 & \\
\hline 61 & A.M. & $\begin{array}{l}1.6 \\
1.4\end{array}$ & $\begin{array}{l}4.0 \\
3.8\end{array}$ & $\begin{array}{l}2.4 \\
2.4\end{array}$ & + & $\begin{array}{l}18 \\
20\end{array}$ & $\begin{array}{l}60 \\
70\end{array}$ & $\begin{array}{l}0 \\
0\end{array}$ & $\begin{array}{l}0 \\
0\end{array}$ & $\begin{array}{l}0 \\
0\end{array}$ & $\begin{array}{l}\text { Six cases of malignant disease } \\
\text { with high total acidities; car- }\end{array}$ \\
\hline & & 1.4 & 3.7 & 2.3 & & 15 & 65 & 0 & 0 & 0 & cinoma of pylorus found at op- \\
\hline 81 & A.M. & 1.3 & 4.1 & 2.3 & + & 10 & 70 & 0 & 0 & 0 & eration in each case. Marked \\
\hline & & 1.7 & 4.3 & 2.6 & & 12 & 60 & 0 & 0 & 0 & rise in every case in spite \\
\hline 82 & A.M. & 1.6 & 3.9 & 2.3 & + & 6 & 53 & 0 & 0 & 0 & of acidity. \\
\hline & & 2.0 & 4.1 & 2.1 & & 15 & 63 & 0 & 0 & 0 & \\
\hline 83 & A.M. & 1.3 & $\begin{array}{l}2.9 \\
3.8\end{array}$ & $\begin{array}{l}1.6 \\
24\end{array}$ & + & $\begin{array}{r}8 \\
15\end{array}$ & $\begin{array}{l}60 \\
60\end{array}$ & $\begin{array}{l}0 \\
0\end{array}$ & 0 & & Peptolytic Index: \\
\hline
\end{tabular}

* A.M. = Material aspirated in morning before giving test breakfast.

There is no doubt that the significance of demonstrable peptolysis of even moderate degree, if observed in aseptic specimens, in much greater than that seen when it is necessary to allow leeway for bacteria and establish empiric borders. From the series of ten non-malignant cases in which we have filtered gastric juice through a Berkefeld filter all peptolysis has disappeared, and it is anticipated further work will show that any peptolysis which survives filtration of this sort is abnormal and likely to mean cancer, provided always that gastric juices containing bile be excluded. For accurate work the aseptic method should be used exclusively. It will be found most practical, perhaps, for ordinary clinical purposes, to dispense with filtration in cases with very low and very high indices and apply it in case of uncertainty; i. e., when the figures are between 20 and 40 . 
It is also important to exclude bacteria when using the qualitative test, since those present in non-malignant cases will sometimes cause a positive reaction. It is possible also that an overgrowth of certain forms, such for instance as lactic acid bacilli, may be responsible for a negative result in a cancer case.

\section{TABLE 7.-MaLignaNT CaSES}

Fourteen cases of carcinoma with free $\mathrm{HCl}, 0$ to 20 ; total acidity, 5 to 70 . Diagnosis confirmed in all but two obvious cases either at operation or at autopsy.

\begin{tabular}{|c|c|c|c|c|c|c|c|c|c|c|}
\hline \multirow{2}{*}{$\begin{array}{l}\text { Case } \\
\text { No. }\end{array}$} & \multicolumn{3}{|c|}{ Formol Titration } & \multirow{2}{*}{ 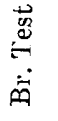 } & \multicolumn{2}{|c|}{ Acidity } & \multirow[b]{2}{*}{$\stackrel{\varrho}{\ddot{\tilde{m}}}$} & \multirow[b]{2}{*}{ 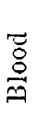 } & \multirow[b]{2}{*}{ 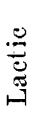 } & \multirow{2}{*}{ Remarks } \\
\hline & First & Second & Rise & & $\mathrm{HCl}$ & Total & & & & \\
\hline 86 & 2.2 & 4.0 & 1.8 & + & 0 & $\dot{5}$ & 0 & 0 & + & $\begin{array}{l}\text { Clinical diagnosis - cancer - } \\
\text { confirmed at operation. }\end{array}$ \\
\hline 93 & 2.1 & 4.2 & 2.1 & + & 0 & 5 & 0 & 0 & + & $\begin{array}{l}\text { Obvious mass, metastases, cach- } \\
\text { exia, death; no autopsy. }\end{array}$ \\
\hline 101 & 2.2 & 4.6 & 2.4 & + & 0 & อ & 0 & 0 & + & $\begin{array}{l}\text { Clinical diagnosis of cancer } \\
\text { confirmed at operation. }\end{array}$ \\
\hline 102 & 2.2 & 4.4 & 2.2 & + & 0 & 5 & 0 & 0 & + & $\begin{array}{l}\text { Clinical diagnosis of cancer } \\
\text { confirmed at operation. }\end{array}$ \\
\hline 37 & 2.2 & 4.5 & 2.3 & + & 0 & 5 & 0 & 0 & + & $\begin{array}{l}\text { Clinical diagnosis of cancer } \\
\text { confirmed at autopsy. }\end{array}$ \\
\hline 58 & 2.4 & 4.6 & 2.4 & + & 0 & 5 & 0 & 0 & 0 & $\begin{array}{l}\text { Clinical diagnosis of cancer } \\
\text { confirmed at autopsy. }\end{array}$ \\
\hline 60 & 2.2 & 3.7 & 1.5 & + & 0 & 10 & 0 & 0 & 0 & $\begin{array}{l}\text { Clinical diagnosis of cancer } \\
\text { confirmed at autopsy. }\end{array}$ \\
\hline $7 \overline{5}$ & 2.2 & 5.1 & 3.0 & 0 & 0 & 10 & 0 & 0 & 0 & $\begin{array}{l}\text { Clinical diagnosis of cancer } \\
\text { confirmed at autopsy. }\end{array}$ \\
\hline 76 & 2.2 & 5.2 & 3.0 & + & 0 & 10 & 0 & 0 & 0 & $\begin{array}{l}\text { Epigastric tumor, nodular liver, } \\
\text { cachexia, no autopsy. }\end{array}$ \\
\hline 84 & 1.9 & 4.0 & 2.1 & + & 0 & 8 & 0 & 0 & $?$ & $\begin{array}{l}\text { Clinical diagnosis of cancer } \\
\text { confirmed at autopsy. }\end{array}$ \\
\hline 99 & 1.5 & 7.0 & 5.5 & + & 0 & 5 & 0 & 0 & + & $\begin{array}{l}\text { Clinical diagnosis, "suspicious": } \\
\text { carcinoma at operation. }\end{array}$ \\
\hline $99 \dagger$ & 1.5 & 5.0 & 3.5 & + & & & & & & \\
\hline 112 & 1.5 & 7.0 & 5.5 & + & 0 & 10 & 0 & 0 & + & $\begin{array}{l}\text { Clinical diagnosis, doubtful; } \\
\text { operation - death, autopsy; } \\
\text { carcinoma. }\end{array}$ \\
\hline $\begin{array}{l}112 \uparrow \\
120\end{array}$ & $\begin{array}{l}1.5 \\
1.5\end{array}$ & $\begin{array}{l}4.4 \\
5.5\end{array}$ & $\begin{array}{l}2.9 \\
4.0\end{array}$ & + & 0 & $\mathbf{5}$ & 0 & 0 & + & $\begin{array}{l}\text { Clinical diagnosis doubtful. Op. } \\
\text { eration showed posterior wall } \\
\text { carcinoma with glandular and } \\
\text { hepatic metastases. }\end{array}$ \\
\hline $120^{+}$ & 1.5 & 4.8 & 3.3 & + & & & & & & \\
\hline 122 & 1.8 & 6.2 & 4.9 & + & 0 & 6 & 0 & 0 & + & $\begin{array}{l}\text { Clinical diagnosis of cancer } \\
\text { confirmed at autopsy. }\end{array}$ \\
\hline $122 \dagger$ & 1.3 & 4.3 & 3.0 & + & & & & & & \\
\hline
\end{tabular}

\section{CONCLUSIONS}

1. Saliva free from bacteria does not split Witte peptone nor glycyltryptophan.

2. Normal gastric juice free from blood, bile (trypsin) and bacteria has no peptolytic power. The same holds true for cases of benign subacidity. 
3. Peptolytic and peptidolytic action exhibited by saliva, and so-called "tryptic" digestion in the stomach when there is no bile to indicate reflux of intestinal contents, are usually due to unfilterable agents (bacteria).

4. There is no incontestable evidence to show that pancreatic juice unaccompanied by bile ever gains access to the stomach (except in cases with acholic intestinal contents).

5. Toluene is inadequate for the exclusion of bacterial action in experiments with saliva and gastric juice.

6. In about 88 per cent. of developed cases, carcinomatous stomach contents show a peptolytic power two to ten times the maximum seen in benign conditions in general. This is due in part to bacteria, but high peptolysis persists after filtration through a Berkefeld and subsequent aseptic handling.

\%. Witte peptone may be advantageously substituted for "ferment diagnosticum" in the Neubauer and Fischer qualitative test, with results in malignant cases as good as any that have been published for glycyltryptophan itself. In non-malignant cases it has been positive but once in seventy-six normal and Subacid cases.

8. The quantitative method herein described yields slightly more uniform results than the qualitative procedure in cancer cases. It has never been found "positive" in seventy-six normal and non-malignant cases.

9. The detection or measurement of peptolytic power in gastric juice, if carried out by any suitable method, is of considerable value in the diagnosis of cancer.

10. It is of value in any case, and essential in doubtful cases, to eliminate bacteria by passage of the gastric juice through a Berkefeld or other equally effective filter, with subsequent aseptic precautions.

\section{IV.-EXPERIMENTAL MATERIAL}

Saliva was obtained from different members of the laboratory staff. The mouth was rinsed with water and the flow promoted by masticating a bit of paraffin. Samples from different individuals were used in some experiments, mixtures in others. The material was filtered through paper or through a Berkefeld candle as indicated on the charts.

Stomach contents were obtained by aspiration one hour after a test breakfast consisting of $30 \mathrm{gm}$. bread and 200 c.c. water. In most instances the stomach was emptied in the morning prior to giving the test breakfast, and the results of both aspirations examined. Unless specified on the charts as "morning aspiration" the material is understood to have been obtained after a test breakfast. In one case the material was obtained at autopsy. Each sample was subjected to a test for bile (dilute alcoholic iodin), for blood (Weber), lactic acid (Uffelmann), and the usual routine titrations, with demethyl-amido-azo-benzol and phenolphthalein. A direct test for tryptophan with dilute bromin water or bromin vapor was also made. Samples giving positive bile or blood reactions, or having a yellow or greenish color even in the absence of positive tests, were not used. The material was filtered through a folded filter or a Berkefeld candle, or both, as indicated in the records. 
Cases were drawn from the Cook County and Presbyterian hospitals, Chicago, the dispensary of Rush Medical College, the private practice of Dr. Jacque and scattering sources. It has been necessary in some malignant cases to rely on the word of the operating surgeon for the final diagnosis, without histological examination. Cases of this sort which have been included have been operated on by surgeons of known competence. For help in obtaining cases, records and material, we are especially indebted to Dr. Donald $A$ tbbott, interne in Cook County Hospital. We also desire to acknowledge the support of Dr. Frank Billings, Dr. James B. Herrick, Dr. A. D. Bevan, Dr. J. Davis and others, for use of material.

METHODS

Peptone Solution.-A 2 per cent. solution of Witte peptone is filtered through a folded filter, distributed in 60 c.c. flasks, sterilized in an autoclave and kept on ice. If the flasks are both eotton- and cork-plugged, the stock solution keeps its titer for a long time. One flask is used for each set of experiments.

\section{PBOCEDURE}

A. (Antiseptic). Ten c.c. gastric juice (filtered through a folded filter) are measured into a flask by means of a pipet. To this are added exactly 20 c.c. peptone solution and, after mixing, a layer of toluene is added. Exactly 10 c.c. of the mixture are withdrawn from under the toluene with a pipet and subjected to formol titration as follows: To the 10 c.c. of mixture add 50 c.c. $\mathrm{H}_{2} \mathrm{O}$ and 5 drops of 1 per cent. alcoholic phenolphthalein, then $\mathrm{N} / 10 \mathrm{KOH}$ to the first permanent pink tint. Take 5 c.c. liquor formaldehydi diluted with 10 c.c. water, add 5 drops phenolphthalein and neutralize in the same way. Add the neutral formol solution to the neutral peptone gastric juice mixture. The mixture becomes acid. Titrate back to the first permanent pink and note the number of tenth cubic centimeters required. ${ }^{2}$

2. Note.-In using phenolpththalein as indicator and bringing to the first permanent pink both for the original neutralization and in the final titration, we intentionally disregard the criticism that for absolute values neutralization with litmus and a final titration to violet with phenolphthalein is preferable. These figures are purely relative and the use of phenolphthalein as proposed by Malfatti for the urinary $\mathrm{NH}_{3}$ is quicker and more satisfactory for this purpose.

The remaining 20 c.c. of peptone gastric juice solution (a) are placed in the incubator for twenty-four hours (stoppered) and at the end of this time 10 c.c. are withdrawn and treated as before. The first titration figure is subtracted from the second and the difference is an expression of the peptolysis which has ocurred in a mixture of $31 / 3$ c.c. gastric juice with $62 / 3$ c.c. peptone solution ("Rise"). The rise multipled by 3 and by 10 gires the figures for peptolysis in 100 c.c. gastric juice with 200 c.c. Witte peptone solution "(Peptolytic Index)." When sufficient material is available it is preferable to use double quantities of gastric juice and peptone solution for the titrations.

B. (Aseptic) The gastric juice is passed through a sterilized kaolin filter (Berkefeld) and subsequently handled in sterile pipets and flasks which are plugged with both cotton and cork. No toluene is used.

The qualitative test is performed by simply adding cautiously to 5 c.c. of the solution to be tested a drop or two of dilute bromin water and observing the delicate rose or rose-violet tint which occurs in presence of tryptophan.

\section{BIBLIOGRAPHY}

Emerson: Der Einfluss des Carcinoms auf die gastrische Verdauungsvorgänge, Deutsch. Arch. f. klin. Med., 1902, lxxii, 415.

Fischer, H.: Zur Kenntnis des carcinomatösen Mageninhalts, Deutsch. Arch. f. klin. Med., 1908, xciii, 98. 
Neubauer and Fischer: Ueber das Vorkommen eines peptidspaltenden Ferments im carcinomatöseñ Mageninhalt und seine diagnostische Bedeutung, Deutsch. Arch. f. klin. Med., xcvii, 499.

Ley, H.: Zur Diagnose des Magencarcinoms Mittels der Fischer Neubauer'schen Methode der Spaltung des Glycyl-Tryptophans, Berl. klin. Wchnschr.. 1911, xlviii, 119.

Pechstein, Heinrich: Ueber den diagnostichen Wert der Glycyl-Tryptophanprobe bei Magencarcinom, Berl. klin. Wchnschr., 1911, xlviii, 375.

Ehrenberg: Ueber des peptidspaltende Vermögen des Mageninhalts und über die Unzuverlässigkeit des von Neubauer und Fischer angegebenen Fermentdiagnostikums, Berl. klin. Wehnschr., 1911, xlviii, 704.

Neubauer and Fischer: Zur Frage der Verwertbarkeit der Glycyl-Tryptophanprobe für die Diagnose des Magencarcinoms, München. med. Wchnschr., 1911, lviii, i74.

Hall and Williamson: The Diagnosis of Gastric Carcinoma by the Cleavage of Polypeptids, Lancet, London, 1911, p. 731.

Weinstein: The New Test for Cancer of the Stomach, with Suggested Improvements, Jour. Am. Med. Assn., 1910, lv, 1085.

Lyle and Kober: The Glycyltryptophan Test for Carcinoma of the Stomach, New York Med. Jour., 1910, xei, 1151.

Kuttner and Pulvermacher: Ueber das Vorkommen und die diagnostische Bedeutung eines peptidspaltenden Enzyms im Mageninhalte, Berl. klin. Wchnschr 1910 , p. 2057.

Oppenheimer: Zur Frühdiagnose des Magencarcinoms. (Tryptophan und eine neue Probe mit Essingsäure), Deutsch. Arch. f. klin. Med., 1910.11, ci, 293.

Warfield: A Peptid-Splitting Ferment in the Saliva, Bull. Johns Hopkins Hosp., 1911, p. 150 .

Koehlker: Ztschr. f. pliysiol. Chem. (Hoppe-Seyler), Nov. 30, 1911.

Weinstein: The Tryptophan Test for Cancer of the Stomach with Special Reference to Peptidolytic Enzyme in the Saliva, Jour. Am. Med. Assn., 1911, lvii, 1420 .

Henriques and Sörensen: Ueber quantitative Bestimmung der Aminosäuren, Polypeptids und der Hippursäure im Harne durch Formoltitration, Ztschr. f. physiol. Chem. (Hoppe-Seyler), 1909. 1xiii, 27.

Malfatti, H.: Die Formoltitration der Aminosäuren im Harne, Ztschr. f. physiol. Chem. (Hoppe-Seyler), 1909, lxi, 499.

Henriques, V.: Ueber quantitative Bestimmung der Aminosäuren im Harne, Ztschr. f. physiol. Chem. (Hoppe-Seyler), lx, 1.

Volhard, Franz: Ueber eine neue Methode der quantitativen Pepsinbestimmung nebst Bemerkungen über die Tryptophanreaction und das Plastein bildende Ferment, München, med. Wehnschr., 1903, ii, 2129.

Glaessner, Karl: Tryptophanreaction und Magencarcinom, Berl. klin. Wchnschr., 1903, p. 599.

Sanford and Rosenbloom: The Glycyltryptophan and Tryptophan Tests for Cancer of the Stomach, The Archives Int. Med., 1912, ix, 445.

Keyser, Curt: Die Leistung des Rïntgenverfáhrens und der Glyzyl-tryptophanreaction für die Diagnose des Magencarcinoms, Deutsch. med. Wchnschr., 1912 , p. 551. 